\title{
Germination responses of Sporobolus ioclados: a saline desert grass
}

\author{
M. Ajmal Khan* \& Salman Gulzar $\dagger$ \\ Department of Botany, University of Karachi, P.O. Box 8452, \\ Karachi-75270, Pakistan
}

(Received 21 November 2001; accepted 28 May 2002)

\begin{abstract}
Sporobolus ioclados (Nees ex Trin.) Nees (Poaceae), a halophytic grass distributed in coastal and inland regions of Pakistan, is a potential forage crop which could be grown in the degraded saline soils of the Indus plain and coastal areas. Greatest germination was obtained in non-saline control and it was linearly reduced with increases in salinity to $500 \mathrm{~mm} \mathrm{NaCl}$. Variation in temperature substantially affected germination in both the saline and nonsaline treatments. At the optimal temperature regime of $20: 30^{\circ} \mathrm{C}$, S. ioclados seeds showed $93 \%$ germination at $0 \mathrm{mM} \mathrm{NaCl}$ and $18 \%$ germination at $500 \mathrm{~mm} \mathrm{NaCl}$, respectively. In all other temperature regimes, only $50 \%$ of the seeds germinated in $0 \mathrm{~mm}$ while none germinated at $500 \mathrm{~mm} \mathrm{NaCl}$. Rate of germination decreased with an increase in salinity at all temperature regimes but comparatively higher rates were obtained at $20: 30^{\circ} \mathrm{C}$. Seeds showed a low recovery response when transferred to distilled water after 20 days of exposure to salinity and tetrazolium viability test showed that most of the ungerminated seeds were dead. The present study showed that if the seed is protected from salinity and temperature stress during storage in the soil, it could germinate during monsoon rains.
\end{abstract}

(C) 2002 Elsevier Science Ltd

Keywords: desert; halophyte; Pakistan; salinity; seed; temperature

\section{Introduction}

Sporobolus ioclados is a stoloniferous perennial grass widely distributed from the sand dunes of the Arabian sea coast to the salt flats and saline deserts in northern Pakistan (Cope, 1982). Aerial shoots sprout from the stoloniferous base after considerable monsoon rains and seed set late in the fall. A large portion of the stored seeds rapidly disappear from the seed bank (Khan, 1993). However, seedlings are recruited from seeds in less saline, dry dune habitats, whereas in salt marshes recruitment through stolons is more common. Sporobolus ioclados populations are distributed in saline wet patches and dry sandy areas on the Karachi University campus where soil-specific conductance varied from 15 to $35 \mathrm{dS} \mathrm{m}^{-1}$ (about 200-400 mM; Khan, 1993) and was found in association with highly salt-tolerant halophytes like Haloxylon stocksii, Suaeda

\footnotetext{
*Corresponding author. Fax: +92-21-4963788. E-mail. ajmal@botany.ku.edu.pk $\dagger$ Department of Botany, Government Superior Science College, Shah Faisal Colony, Karachi-75230, Pakistan.
} 
fruticosa and Salsola imbricata in inland communities and with Halopyrum mucronatum, Tamarix indica, Aeluropus lagopoides, Salsola imbricata, Suaeda fruticosa and Heliotropium curassavicum in the coastal communities. Some Sporobolus species are known to be dormant after seed dispersal (Andrews, 1997) and are moderately salt tolerant at germination (Mahmood \& Malik, 1996).

Grasses vary in their upper limit of salt tolerance and increases in salinity usually delay seed germination (Gulzar \& Khan, 2001). Halophytic grasses like S. virginicus (Breen et al., 1997), Puccinellia nuttalliana (Macke \& Ungar, 1971), H. mucronatum (Khan \& Ungar, 2001), Hordeum vulgare (Badger \& Ungar, 1989) and Briza maxima (Lombardi et al., 1998) germinate in $\mathrm{NaCl}$ concentrations up to $350 \mathrm{~mm}$. However, Urochondra setulosa (Gulzar et al., 2001), P. festucaeformis (Onnis \& Micelli, 1975), A. lagopoides (Gulzar \& Khan, 2001) and Spartina alterniflora (Mooring et al., 1971) have been shown to germinate at $500 \mathrm{~mm}$ or higher $\mathrm{NaCl}$ levels.

Temperature influences the germination responses of many halophytic grasses to salinity (Badger \& Ungar, 1989; Delesalle \& Blum, 1994; Khan \& Ungar, 1999, 2001). Gulzar et al. (2001) studied the effect of salinity and temperature on the germination of $U$. setulosa. They found that a temperature regime of $20: 30^{\circ} \mathrm{C}$ significantly promoted germination. Similar results were reported for A. lagopoides, a grass distributed in the study area (Gulzar \& Khan, 2001).

Seeds of various halophytic grasses maintain ability to germinate after an extended period of exposure to salinity (Macke \& Ungar, 1971; Breen et al., 1977; Zedler et al., 1990; Keiffer \& Ungar, 1995, 1997), which could change with treatments at different temperature regimes (Khan \& Ungar, 1997, 1999, 2001; Gulzar \& Khan, 2001; Gulzar et al., 2001). Exposure to high salinity could cause priming of seeds before germination or the higher salinity could result the death of seeds (Ungar, 1995). This study was conducted to better understand the seed germination requirements of $S$. ioclados population from the near coastal areas of Karachi, Pakistan. Initial establishment of species in salt deserts is related to germination response of seeds to salinity and temperature regimes and early establishment usually determines if a population will survive to maturity (Gulzar \& Khan, 2001). The effects of salinity and temperature regimes on percentage of germination, rate of germination, and recovery responses of $S$. ioclados were studied to determine their individual effect and the interaction between these factors on germination.

\section{Materials and methods}

Inflorescences of $S$. ioclados were collected from a population on the Karachi University campus. Seeds were separated from the inflorescence, cleaned and dry stored at room temperature after surface sterilization with $8.5 \%$ clorox for 1 min. Seeds were germinated in two folds of Whatman filter \# 1 paper placed in $2.5 \mathrm{~cm} \times 18 \mathrm{~cm}$ glass test tubes with $5 \mathrm{ml}$ of test solution. Four replicates of 25 seeds each were used for each treatment. A seed was considered to have germinated at the emergence of the radicle (Bewley \& Black, 1994). Six salinity concentrations $(0,100$, 200, 300, 400, and $500 \mathrm{~mm} \mathrm{NaCl}$ ) were used based on a preliminary test for salt tolerance limits of the species. Germination was tested at 10:20, 15:25, 20:30 and $25: 35^{\circ} \mathrm{C}$ temperature regimes with a 12 -h photoperiod using $25 \mu \mathrm{mol} \mathrm{m}^{-2} \mathrm{~s}^{-1}, 400$ $700 \mathrm{~nm}$ Sylvania cool white fluorescent lamps. Germination was noted on alternate days for 20 days. After 20 days, all un-germinated seeds were placed in distilled water and under the initial temperature regimes for another 20 days. Un-germinated seeds were tested for viability using the tetrazolium chloride test (Copeland \& McDonalds, 1995). Rate of germination and recovery were calculated with the help of a modified Timson's germination velocity index $=\Sigma G / t$, where $G$ is the percentage of seeds 
germinated after 20 days, and $t$ the total time of germination (Khan \& Ungar, 1999). The maximum possible value using our data was 50 (1000 seeds 20 days $\left.^{-1}\right)$. Percentage recovery germination was calculated by using the following formula $=(a-$ $b) /(c-b) \times 100$, where $a$ is the total number of seeds germinated after being transferred to distilled water, $b$ the total number of seeds germinated in saline solution and $c$ the total number of seeds. Germination data (20 days and rate of germination) and recovery germination data (20 days) were arcsine transformed before statistical analysis to ensure homogeneity of variance.

Data were analysed using SPSS 9.0 (SPSS, 1999). The effect of salinity and temperature on the rate and percentage of germination were examined using two-way analysis of variance (ANOVA). If significant differences occurred, a Bonferroni analysis (Multiple range test, $p<0.05$ ) was carried out to determine if significant differences occurred between individual treatments. Linear regression analysis was used to determine the relationships between germination, rate of germination, recovery of germination and salinity at different temperature regimes.

\section{Results}

Germination of $S$. ioclados seeds decreased with an increase in salinity (Fig. 1). Germination was greatly reduced in the $500 \mathrm{~mm} \mathrm{NaCl}$ treatment. Alternating temperature regimes of $20: 30^{\circ} \mathrm{C}$ yielded maximum germination at all salinities tested (Figs 1 and 2). Germination at other temperature regimes, i.e. 10:20, 15:25 and $25: 35^{\circ} \mathrm{C}$ had a similar pattern of germination at or above $300 \mathrm{~mm} \mathrm{NaCl}$. A two-way ANOVA of germination indicated a significant main effect of salinity $(F=46 \cdot 9$, $p<0.0001)$, temperature $(F=56.7, p<0.0001)$ and their interaction $(F=3 \cdot 6$, $p<0 \cdot 0001)$. There was a strong negative relationship with germination and salinity with coefficient of determination $\left(r^{2}\right)$ ranging from 0.60 to $0 \cdot 79$ (Fig. 2).

Germination velocity significantly $(p<0.001)$ decreased with an increase in salinity in all temperature treatments (Fig. 3). Rate of germination in the various salinity treatments was usually highest at the $20: 30^{\circ} \mathrm{C}$ temperature regime. A two-way ANOVA of rate of germination indicated a significant main effect of salinity $(F=57 \cdot 8$,

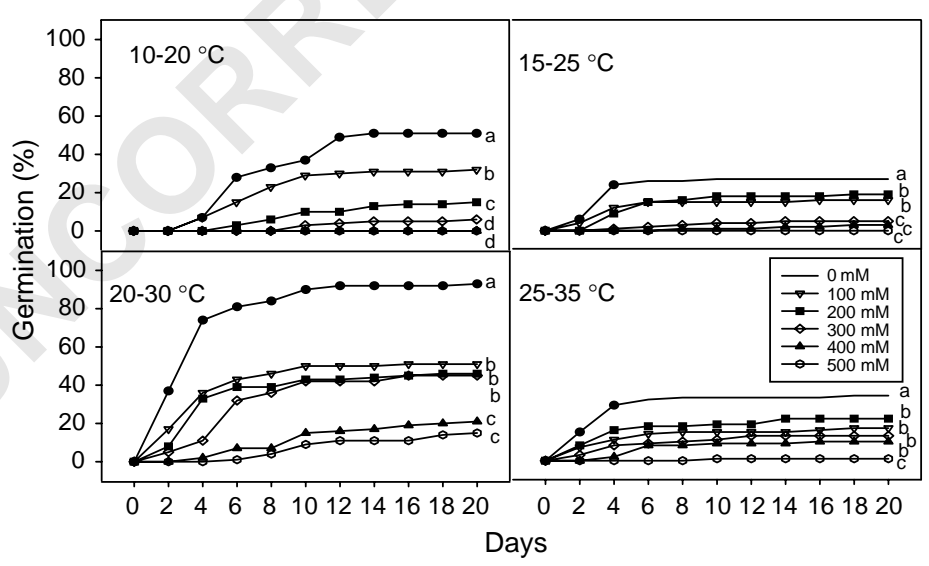

Figure 1. Germination of Sporobolus ioclados seeds in 0, 100, 200, 300, 400 and $500 \mathrm{mM} \mathrm{NaCl}$ and $10-20,15-25,20-30$ and $25-35^{\circ} \mathrm{C}$ temperature regimes. Values at each temperature regime having the same letter are not significantly different $(p>0.05)$ from the control (Bonferroni test). 


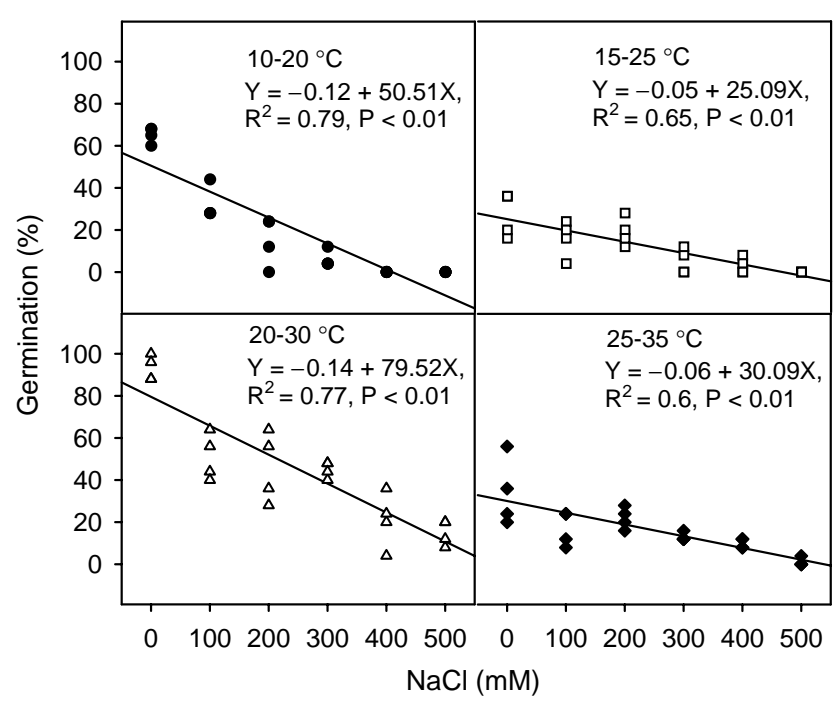

Figure 2. Regression plots for mean final germination percentages of Sporobolus ioclados seeds in $0,100,200,300,400$ and $500 \mathrm{~mm} \mathrm{NaCl}$ and $10-20,15-25,20-30$ and $25-35^{\circ} \mathrm{C}$ temperature regimes.

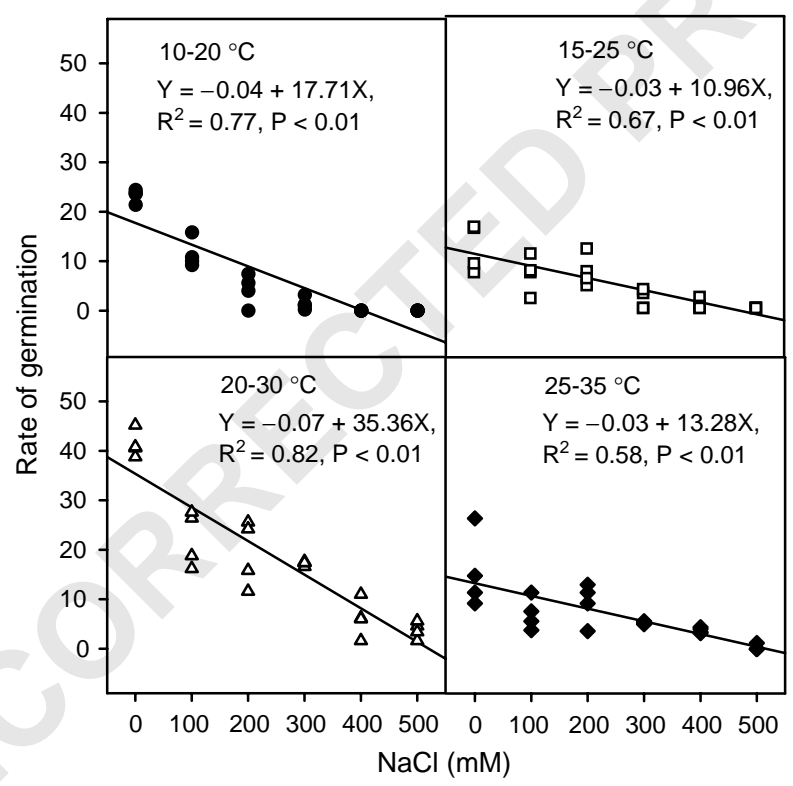

Figure 3. Regression plots for rate of germination of Sporobolus ioclados seeds in 0, 100, 200, 300,400 and $500 \mathrm{~mm} \mathrm{NaCl}$ and $10-20,15-25,20-30$ and $25-35^{\circ} \mathrm{C}$ temperature regimes.

$p<0.0001)$, temperature $(F=61 \cdot 2, p<0.0001)$ and their interaction $(F=5 \cdot 0$, $p<0.0001)$. A linear regression explains a high promotion of the germination response with $r^{2}$ values ranging from 0.58 to 0.82 in various temperature treatments (Fig. 3).

After a 20 day salinity treatment, seeds were transferred to distilled water to determine the recovery of germination in seeds inhibited by salt treatment. Recovery 


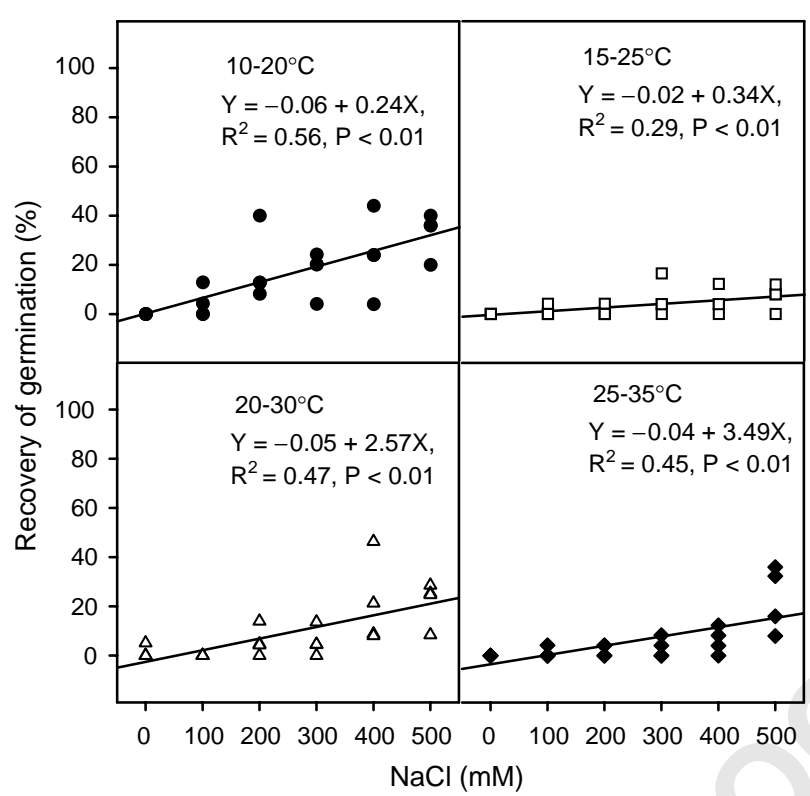

Figure 4. Regression plots for recovery of germination of Sporobolus ioclados seeds in 0, 100, $200,300,400$ and $500 \mathrm{~mm} \mathrm{NaCl}$ and $10-20,15-25,20-30$ and $25-35^{\circ} \mathrm{C}$ temperature regimes.

of germination was generally low and highest recovery was about 30\% (Fig. 4). At low $\mathrm{NaCl}$ concentration, there was no recovery of germination while seeds exposed to high salinity ( $500 \mathrm{~mm} \mathrm{NaCl}$ ) had some recovery of germination (Fig. 4). A linear regression plot depicted the recovery of germination at various salinity concentrations with $r^{2}$ values ranging from $0 \cdot 29$ to 0.56 (Fig. 4). Most of the un-germinated seeds were not viable after the recovery treatment.

\section{Discussion}

Saline areas in Pakistan have about 60 perennial grasses (Khan, 2002) and about 18 of them are found in the coastal areas (Khan \& Gul, 2002). Salt-tolerant grasses could be used as a fodder or as turf grasses in the areas where good quality water deficits are present and soils are saline (Khan, 2002). Sporobolus ioclados is one of the most common grasses found in the saline marshes and saline deserts of Pakistan (Cope, 1982). It grows in the coastal dunes and marshes of saline basin and sand dunes found in the Indus plains and could be used as a forage grass (Khan, 2002). Our data indicate that the seeds of $S$. ioclados were not dormant and showed $93 \%$ germination at a $20: 30^{\circ} \mathrm{C}$ temperature regime. However, a change in temperature substantially affected the percent germination. Germination in S. ioclados seeds was inhibited with an increase in salinity but some seeds germinated at $500 \mathrm{~mm} \mathrm{NaCl}$. It seems that most of the grasses studied showed little germination above $300 \mathrm{~mm} \mathrm{NaCl}$ (Macke \& Ungar, 1971; Ungar, 1974; Breen et al., 1977; Khan \& Ungar, 2001) while some could tolerate up to $500 \mathrm{~mm}$ (Onnis \& Micelli, 1975; Gulzar et al., 2001; Gulzar \& Khan, 2001) with the exception of Spartina alterniflora which could germinate at about $1000 \mathrm{~mm} \mathrm{NaCl}$. Tolerance to salinity at the seed germination stage by $S$. ioclados indicates that it is one of the highly salt-tolerant grasses. 
A number of environmental factors may be involved in the development of germination strategies of halophytic seeds (Ungar, 1995). Temperature is reported to be one of the crucial factors in modulating seed germination responses under saline conditions (Khan, 1999). Sporobolus ioclados seeds) germinated better at 20:30 C regime and any further increases or decreases in temperature inhibited germination at all salinities. Similar sensitivity to change in temperature is also shown by other grasses (Macke \& Ungar, 1971; Morgan \& Myers, 1989; Myers \& Couper, 1989; Khan \& Ungar, 2001). Other Arabian Sea coastal grasses like A. lagopoides, H. mucronatum and Urochondra setulosa showed similar responses to change in temperature and highest germination was obtained at $20: 30^{\circ} \mathrm{C}$ (Gulzar \& Khan, 2001; Gulzar et al., 2001; Khan \& Ungar, 2001). Temperature shifts may affect a number of processes determining the germinability of seeds including membrane permeability, activity of membrane-bound proteins and cytosol enzymes (Bewley \& Black, 1994).

Seeds of halophytes have been found to germinate even after prolonged exposure to hyper-saline conditions (Keiffer \& Ungar, 1997; Khan \& Ungar, 1997). Seeds of halophytic grasses recovered quickly when exposed to salinity for short periods and under suitable temperature regimes (Keiffer \& Ungar, 1997; Gulzar \& Khan, 2001; Khan \& Ungar, 2001; Gulzar et al., 2001). A longer exposure and unfavorable temperature conditions can prevent their recovery from salinity stress (Keiffer \& Ungar, 1997; Gulzar et al., 2001). Sporobolus ioclados seeds, however, showed an overall poor recovery response at all temperature regimes when transferred to distilled water after 20 days salinity of treatment. The tetrazolium test after the recovery showed that the exposure to high concentration of salinity and unfavorable temperature regimes caused the loss of viability. This response is dissimilar to other grass species from the same locality like $U$. setulosa and $A$. lagopoides which showed good recovery from salinity stress (Gulzar et al., 2001; Gulzar \& Khan, 2001) while the highest salinity treatment $(500 \mathrm{~mm})$ had a priming effect on seed germination of A. lagopoides at optimal temperatures.

Sporobolus ioclados usually grows both in coastal an inland salt marshes and deserts. Its habitat varies from dry sand dunes to salt marshes. The plant produces seeds in fall when conditions are dry and soil salinity levels are high. Monsoon rains (from July through August) substantially decrease the soil salinity levels due to leaching. The increase in relative humidity results in high cloud cover thereby decreasing the mean ambient temperature from $31^{\circ} \mathrm{C}$ in June to $27^{\circ} \mathrm{C}$ in August. This provides conditions that are apparently ideal for the recruitment of $S$. ioclados. Our laboratory results also showed best germination at $20-30^{\circ} \mathrm{C}$ temperature regime. Seeds present on the dry sand dunes are usually buried under sand and are therefore protected from temperature and salinity stress. Therefore, they readily germinate after the considerable monsoon rains. Salt marsh environments, however, exposes seeds to both salinity and temperature stress which causes high seed mortality. This may explain why the recruitment from seeds in the salt marsh habitat is rare. Seedlings, which survive have the ability to tolerate high salinity and could grow in up to $500 \mathrm{~mm}$ $\mathrm{NaCl}$ (Gulzar \& Khan, unpublished data). Sporobolus ioclados is highly sensitive to salinity and temperature while in the seed bank but is highly salt tolerant at germination and growth stages. Sporobolus ioclados could be used as a forage crop on the saline dunes present in both coastal and inland areas of Pakistan.

\section{References}

Andrews, T.S. (1997). Factors affecting the germination of Giant Parramatta grass. Australian Fournal of Experimental Agriculture, 37: 439-446.

Badger, K.S. \& Ungar, I.A. (1989). The effects of salinity and temperature on the germination of the inland halophyte Hordeum jubatum. Canadian fournal of Botany, 67: 1420-1425. 
Bewley, J.D. \& Black, M. (1994). Seeds: Physiology of Development and Germination. London: Plenum Press. 445 pp.

Breen, C.M., Everson, C. \& Rogers, K. (1997). Ecological studies on Sporobolus virginicus (L) Kunth with particular reference to salinity and inundation. Hydrobiologia, 54: 135-140.

Cope, T.A. (1982). Poaceae (No. 143). In: Nasir, E. \& Ali, S.I. (Eds.), Flora of Pakistan. Karachi: Department of Botany, University of Karachi. 680 pp.

Copeland, L.O. \& McDonald, M.B. (1995). Seed Science and Technology. New York: Chapman \& Hall. $\square \square$ pp.

Delesalle, V.A. \& Blum, S. (1994). Variation in germination and survival among families of Sagittaria latifolia in response to salinity and temperature. International fournal of Plant Science, 155: 187-195.

Gulzar, S. \& Khan, M.A. (2001). Seed germination of a halophytic grass Aeluropus lagopoides. Annals of Botany, 87: 319-324.

Gulzar, S., Khan, M.A. \& Ungar, I.A. (2001). Effect of salinity and temperature on the germination of Urochondra setulosa. Seed Science and Technology, 29: 21-29.

Keiffer, C.W. \& Ungar, I.A. (1995). Germination responses of halophyte seeds exposed to prolonged hypersaline conditions. In: Khan, M.A. \& Ungar, I.A. (Eds.), Biology of Salt Tolerant Plants. pp. 43-50. Karachi: University of Karachi. $\square$ pp.

Keiffer, C.W. \& Ungar, I.A. (1997). The effect of extended exposure to hypersaline conditions on the germination of five inland halophyte species. American fournal of Botany, 84: 104-111.

Khan M.A. (1993). Relationship of seed bank of plant distribution in saline arid communities. Pakistan fournal of Botany, 25: 73-82.

Khan M.A. (1999). Comparative influence of salinity and temperature on the germination of subtropical perennial halophytes. Halophyte uses in different climates I: ecological and ecophysiological studies. In: Lieth, H., Moschenko, M., Lohman, M., Koyro, H-W. \& Harndy, A.) (Eds.), Progress in Biometeriology, pp. 77-88. Netherlands: Backhuys Publishers, $\square$ pp.

Khan, M.A. (2002). An ecological overview of halophytes from Pakistan. In: Lieth, H. \& Moschenko, M. (Eds.), Cash Crop Halophytes: Potentials, Pilot Projects, Basic and Applied Research on Halophytes and Saline Irrigation 10 years after Al-Ain Meeting (in press). Netherlands: Kluwer Academic Press. $\mathbf{\square} \mathbf{0 p}$.

Khan, M.A. \& Gul, B. (2002). Salt tolerant plants of coastal sabkhas of Pakistan. In: Barth, \& H. Boer, B. (Eds.), Sabkha Ecosystems: Vol. 1: The Arabian Peninsula and Adjacent Countries, pp. 123-140. Netherlands: Kluwer Academic Press. $\square \square$ pp.

Khan, M.A. \& Ungar, I.A. (1997). Effect of thermoperiod on recovery of seed germination of halophytes from saline conditions. American fournal of Botany, 84: 279-283.

Khan, M.A. \& Ungar I.A. (1999). Seed germination and recovery of Triglochin maritima from salt stress under different thermoperiods. Great Basin Naturalist, 59: 144-150.

Khan, M.A. \& Ungar, I.A. (2001). Seed germination characteristics of Halopyrum mucronatum: a coastal sand dune grass from Pakistan. Australian fournal of Botany, 49: 777-783.

Lombardi, T., Fochetti, T. \& Onnis, A. (1998). Germination of Briza maxima L. seeds: effects of temperature, light, salinity and seed harvesting time. Seed Science and Technology, 26: 463-470.

Macke, A. \& Ungar, I.A. (1971). The effect of salinity on germination of Puccinellia nuttalliana. Canadian fournal of Botany, 49: 515-520.

Mahmood, K. \& Malik, K.A. (1996). Seed germination and salinity tolerance in plant species growing on saline wastelands. Biologia Plantarum, 38: 309-315.

Mooring, M.T., Cooper, A.W. \& Seneca, E.D. (1971). Seed germination response and evidence for height of ecophenes in Spartina alterniflora from North Carolina. American fournal of Botany, 58: 48-56.

Morgan, W.C. \& Myers, B.A. (1989). Germination characteristics of the salt tolerant grass Diplachne fusca. I. Dormancy and temperature responses. Australian fournal of Botany, 37: 225-237.

Myers B.A. \& Couper D.I. (1989). Effects of temperature and salinity on the germination of Puccinellia ciliata (Bor.) cv. Menemen. Australian Fournal of Agricultural Research, 40: 561-571.

Onnis, A. \& Miceli, P. (1975). Puccinellia festucaeformis (Host) Parl.: Dormienza e influenza della salinia sulla germinazione. Giornale Botanico Italiano, 109: 27-37.

SPSS. (1999). SPSS: SPSS 9.0 for Windows Update. U.S.A.: SPSS Inc.

Ungar, I.A. (1974). The effect of salinity and temperature on Seed germination and growth of Hordeum jubatum. Canadian Fournal of Botany, 52: 1357-1362. 
Ungar, I.A. (1995). seed germination and seed-bank ecology in halophytes. In: Kiegel, J. \& Galili, G. (Eds.), Seed Development and Seed Germination, pp. 599-628. New York: NY: Marcel and Dekker $\square \mathbf{\square p}$.

Zedler, J.B., Pauling, E. \& McComb, A. (1990). Differential responses to salinity help explain the replacement of native funcus krausii by Typha orientalis in Western Australia salt marshes. Australian fournal of Ecology, 15: 57-72. 